http://dx.doi.org/10.14393/HeP-v30n57-2017-3

\title{
COSTUREIRAS E AS MUDANÇAS NAS RELAÇÕES DE TRABALHO EM SANTA HELENA, PR*
}

Rosane Marçal da Silva**

RESUMO: As questões desenvolvidas neste artigo centraram-se na discussão e na problematização de elementos e dimensões do processo de intensificação da produção industrial e das mudanças que o trabalho industrial ocasionou na vida dos trabalhadores das indústrias de confecções do vestuário, em Santa Helena-PR, durante os anos 1980 a 2000. Para isso, utilizo-me de narrativas produzidas com os trabalhadores.

PALAVRAS-CHAVE: Trabalho. Trabalhadores. Indústrias do vestuário.

ABSTRACT: The topics developed in this article focuses on discussing and problematizing elements related to the growth process of the industrial production and changes in their lives caused by this kind of industrial work Santa Helena in the period 1980-2000. For this, I use some oral accounts from workers.

KEYWORDS: Job. Workers. Clothing industries.

* Este artigo liga-se à pesquisa desenvolvida durante o curso de doutorado realizado no Programa de Pós-Graduação em História da Universidade Federal de Uberlândia, sob orientação do Prof. Dr. Rinaldo José Varussa.

** Professora Doutora em História Social pela Universidade Federal de Uberlândia. 


\section{Introdução}

Para investigar e analisar as trajetórias dos trabalhadores das indústrias de confecções do vestuário, colocando em destaque as mudanças que o trabalho industrial ocasionou na vida desses sujeitos em Santa Helena-PR, durante os anos 1980 a 2000, fez-se necessário o uso da história oral, pois buscava colocar em pauta as interpretações dos próprios sujeitos que vivenciaram a experiência do trabalho fabril ${ }^{1}$. Esta escolha foi parte de um posicionamento enquanto ser social que também experimentou tais relações e que viu nas entrevistas orais o caminho para a compreensão das dinâmicas do trabalho industrial e de sua complexidade, uma vez que, nas entrevistas, seria possível encontrar elementos para esclarecer aspectos silenciados pela produção dominante. ${ }^{2}$

As primeiras confecções registradas (1989, 1994, 1995, 1996 e 1999) trabalhavam com malhas envolvendo a produção de cortinas, lingeries e uniformes escolares e empresarias. A maior expansão desse setor aconteceu nos anos 2000, quando havia 14 empresas registradas, sendo 9 especializadas na produção de jeans. Possivelmente, esta expansão resulta da propagação dos incentivos fornecidos pela prefeitura do município de Santa Helena mediante o programa de concessão de uso. Isso pode ser depreendido no processo de formação dessas empresas.

Contabilizando as empresas da indústria do vestuário registradas entre 1989 e 2013 , obtive um total de $19^{3}$, elas estavam

1 Os trabalhadores foram identificados com pseudônimos.

2 Para analisar as experiências e trajetórias de vida e trabalho dos trabalhadores, dialoguei com as reflexões de Alessandro Portelli e Yara Aun Khoury, pois ambos compreendem que, ao falarem, as pessoas se posicionam como sujeitos dos processos que vivem em sociedade e estabelecem relações sociais, interpretam e expressam seus valores culturais. As experiências são constituídas de uma realidade social, ou seja, são de origem social. Cf.: Portelli, 1996; Khoury, 2004.

3 Além dessas industrias de confecções do vestuário, havia 2 ateliês de costura e 13 costureiras domiciliares registradas. Os números de ateliês e 
instaladas na sede e nos distritos do município e empregavam entre 4 e 120 pessoas, num total de 632 trabalhadores contratados. Os dados indicados apontam uma porcentagem maior de facções industriais4 $(12)^{5}$, ante 1 facção domiciliar. 0 número de estabelecimentos especializados na produção de jeans - incluindo shorts, saias, jaquetas e, sobretudo, calças - era maior (11), se comparado com as confecções especializadas em uniformes escolares e empresariais, lingeries, cortinas e roupa social masculina (8).

Nos anos 1980, Santa Helena ${ }^{6}$ passava por mudanças

de costureiras domiciliares indicam só os estabelecimentos localizados na sede municipal de Santa Helena, PR.

4 Optei por adotar o princípio utilizado por Angela Maria de S. Lima, que classificou as confecções em facções domiciliares e industriais, compreendendo que as facções industriais são empresas de pequeno ou médio porte que prestam serviços a outras empresas ou outras facções maiores, que possuem geralmente mais de 10 funcionários, nem sempre registrados (LIMA, 2009, p. 91). Facções domiciliares caracterizavam-se como pequenas e não tinham marca própria nem estilista ou desenhista. Produziam roupas "integralmente ou peças específicas parceladamente e que, às vezes, insere nela a marca do produto da empresa ou das empresas contratantes" (LIMA, 2009, p. 91). Em Santa Helena, as facções domiciliares eram ocupadas, em geral, por cerca de cinco trabalhadoras, às vezes com membros da família, tais como filhos, e vizinhas ou pessoas próximas que executavam as operações. Fora da estrutura das fábricas, se encontravam as costureiras domiciliares e as faccionistas (ABREU, 1986, p. 154). Nessa estruturação também encontrei um grupo de costureiras autônomas que exerciam suas profissões em suas casas ou em "puxados" construídos no fundo de seus quintais.

5 Não inclui as empresas que confeccionavam cortinas, enxovais, lingeries, uniformes escolares e empresarias, pois sua dinâmica de organização difere das facções industriais e domiciliares ligadas à produção de roupas.

Localizada na microrregião do extremo oeste do Paraná, às margens do Lago de Itaipu, Santa Helena dista 619 quilômetros da capital, Curitiba. Com população estimada em 24.895 habitantes (conforme Censo Demográfico de 2013, realizado pelo Instituto Brasileiro de Geografia e Estatística - IBGE), o município se limita com Entre Rios do Oeste, ao norte; com Missal e Itaipulândia, ao sul; com São José das Palmeiras e Diamante do Oeste, ao leste; e com a República do Paraguai (Lago de Itaipu), a oeste. Conforme 
vinculadas à formação do Lago de Itaipu e suas consequências para a cidade e a população lá residente. A preocupação com as consequências da formação da Usina Hidrelétrica de Itaipu para a região e os rumos administrativos que assumiriam a partir de então era compartilhada pelo conjunto dos municípios, em especial aqueles localizados às margens do Lago. O momento exigia a construção de outras relações políticas econômicas e sociais e, diante disso, as classes dominantes viam como alternativa econômica e referencial de "desenvolvimento" a tentativa de industrialização por meio da constituição de um parque industrial e da instalação de indústrias. Assim, se estabeleceu um processo de deslocamento de algumas indústrias e de criação de outras. ${ }^{7}$

Na perspectiva dominante, a formação do Lago desembocou num movimento de industrialização e constituição urbana das cidades do oeste do Paraná, porque, com o alagamento das terras, alguns daqueles sujeitos que sobreviviam do trabalho agrícola perderam suas formas de sobrevivência e precisaram se deslocar para as cidades.

Desse processo, os setores ligados ao poder político e

informações extraídas do website da Itaipu, Santa Helena foi o município que teve a maior área alagada pela formação do Lago, num total de 263,76 quilômetros quadrados. Por isso, recebe uma quantidade maior de royalties da Itaipu Binacional, cuja distribuição é proporcional à área alagada dos municípios e cujos porcentuais são definidos pela Agência Nacional de Energia Elétrica (ANEEL). Cf.: AGÊNCIANACIONAL DE ENERGIAELÉTRICA (ANEEL). Royalties de municípios alagados pela formação do Lago de Itaipu. Disponível em: <http://www.itaipu.gov.br/responsabilidade/royalties>. Acesso em: 1. fev. 2013.

7 Estudos na área da Geografia buscaram explicações para o processo de industrialização no oeste do Paraná nos fatores territoriais, com o argumento de que a localização das indústrias é importante para analisar a perspectiva de desenvolvimento regional. Esses estudos apontam também que as políticas de incentivos à industrialização têm constituído uma das estratégias do capitalismo contemporâneo, com a busca de regiões pouco industrializadas que ofereçam condições política e economicamente favoráveis. Indústrias de produtos alimentícios e do vestuário têm se deslocado para a região oeste do Paraná, aproveitando-se do que os governos estaduais e municipais oferecem como atrativos (GEMELLI, 2011). 
empresarial costumavam frisar aquilo que enxergavam como positivo, a saber: que a formação do Lago propiciou a constituição de uma cidade turística e a intensificação da atividade industrial. Os projetos de turismo e de industrialização são vistos pelos setores dominantes como símbolo de "desenvolvimento" proporcionado pelo Lago. Essa formulação se configurou a partir de 1990, quando o município de Santa Helena se projetava como "local de progresso" a resultar dos royalties pagos pela Itaipu Binacional (LANGARO, 2005, p. 66; SILVA, 2011). Tais projetos passaram a compor a pauta da administração como propostas de crescimento econômico e social que colocariam o município numa nova etapa, supostamente benéfica à cidade e aos santahelenenses.

Como resposta a esse contexto dos anos 1980, o governo municipal lançava suas expectativas no futuro, ou seja, acreditava na industrialização. Líderes do governo acreditavam que a industrialização seria uma forma de "adaptar" a economia municipal "[...] às necessidades e imposições de um novo tempo." (GIOVANELLA; COPINI, 1988, p. 12).

Embora tenha sido entre os anos 1990 e 2000 que houve uma expansão do número de empresas e do pessoal empregado em confecções do vestuário, antes desse período já existiam trabalhadores sobrevivendo de costura realizada em seus domicílios e sem registro formal. Exemplo deles é Salomé, que disse ter, desde criança, o "dom" da costura: "[...] fazia roupa de boneca com a agulha [...]". Por volta de 1980, aos 13 anos de idade, ela fez o curso de costura e iniciou suas atividades como "costureira doméstica": "[...] sempre tinha mais pedidos do que eu mesma conseguia [...]. Com 16 anos, eu casei. Já costurava na casa dos meus pais, né? Como costureira doméstica. Depois, casei e sempre continuei na mesma profissão." (SALOMÉ, 7 out. 2013).

Costureiras que, nos anos 1980, laboravam em seus domicílios, em geral residiam no meio rural; em meados de 1990, mudaram-se para a sede municipal a fim de constituir empreendimento próprio. Esse processo ocasionou mudanças em 
suas vidas e na vida do conjunto dos trabalhadores ligados a esse setor de produção. Elas registraram tais mudanças demarcando diferenças entre o labor domiciliar e o industrial. Com efeito, a passagem da atividade domiciliar para a constituição de empresas é comum na trajetória das empresárias do ramo de confecções, sobretudo aquelas especializadas na produção com tecidos leves, tais como uniformes, lingerie, cortinas, enxoval e decoração.

As costureiras domiciliares que constituíram empresas pareciam contar suas trajetórias com o objetivo de exaltar sua posição no presente. Foi perceptível que, dentre algumas empresárias, a identificação e o reconhecimento do lugar social que ocupavam estavam entrelaçados com o fato de serem trabalhadoras que produzem e serem patroas. Ao falar das condições e da rotina laboral, estas empresárias demonstravam objetivos diferentes daqueles que prestavam serviços para alguma facção e até das costureiras domiciliares sem vínculo com empresas. ${ }^{8}$

As trajetórias das entrevistadas mostram que, num momento, podiam estar em casa costurando e, noutro, empregarem-se nas indústrias como costureiras internas. Essa complexidade e heterogeneidade laboral parecem especificar a condição de trabalhadores num contexto de mudanças em que passam da atividade informal àquela formalizada pelo registro em carteira. Nesse contexto de diversificação e fragmentação nas formas de produção de roupas, as trabalhadoras se colocam como sujeitos que almejam e criam mecanismos para obter condições laborais melhores; e uma dessas formas está na constituição do próprio negócio.

Com a formação dessas empresas, as relações laborais nesse setor foram se configurando e apresentando mudanças nas experiências vividas pelos trabalhadores. Nessas relações, pude identificar duas linhas de diferenciação: quem tinha registro formal e quem não tinha. A primeira categoria incluía internos das

8 Para o aprofundamento das trajetórias das empresárias e a formação das empresas, ver: Silva, 2016. 
facções industriais; a segunda, externos e costureiras domiciliares sem ligação com empresas. Os internos e os que estavam nas facções informais realizavam tarefas parceladas, mas aqueles sem vínculo com empresa tinham uma atividade que implicava fazer a peça inteira. Os externos trabalhavam por produção; os internos poderiam receber prêmio de produção se atingissem a meta estabelecida pelos empresários.

A produção no interior das fábricas de jeans tendia a ser dividida em seis setores: onde se carimbavam os pacotes de acordo com as tonalidades do tecido, da cor e do tamanho; onde se produzia a frente das peças; onde se produziam as partes traseiras; onde se montavam as peças - junção da frente com a traseira; onde se pregavam cós e se colocavam passantes - chamado de "cantinho"; enfim, onde se tiravam fios e se empacotavam as peças para encaminhar às lavanderias. Normalmente, as lavanderias eram firmas contratadas pelos empresários e estavam localizadas em outros municípios. Nelas, as peças passavam pela alteração da coloração e da textura do tecido.

\section{Experiências na indústria do vestuário e as transformações na vida dos trabalhadores}

Dos 36 entrevistados, 9 não trabalhavam na indústria de confecção. Destes, 3 haviam pedido demissão porque conseguiram emprego em outro setor; Rosário fez o curso de costura industrial, mas não atuou no setor, pois tinha magistério e foi lecionar numa escola; Mônica atuou durante 15 dias e foi demitida; Tereza pediu demissão porque estava grávida; Edwiges parou de trabalhar porque a empresa foi desativada por causa de um vendaval que destruiu o barracão; Jezabel e Rebeca não estavam ligadas a nenhuma empresa - faziam serviço de costura somente para a família. Havia uma entrevistada que estava no seguro-desemprego, pois foi demitida após estabelecer contato com o sindicato dos costureiros, e outra que estava desempregada. 
O processo que levou as trabalhadoras ao trabalho industrial podia variar, porém todas ressaltaram a busca de um trabalho para garantir sua subsistência e de sua família. Jezabel trabalhava com seu esposo na agricultura, mas, por volta de 1990, sua família passou por dificuldades econômicas e precisou procurar emprego na indústria de confecção de roupas. No trecho abaixo, ela salienta as transformações que afetaram as relações de trabalho de que vivia no campo:

[...] A dificuldade apertou, a gente não tinha dinheiro pra sobrevivência, e eu optei por arrumar emprego [...]. Fui pra sala de costura, me dei bem trabalhando de costura, e ela [a empresaria] me deu o emprego de costura. E, daí, eu ia daqui a pé, ou de bicicleta, trabalhava o dia inteiro lá e daí vinha pra casa atendê o meu serviço. Não era tão leviano [leve] assim, né? Porque tinha que saí 5 horas da manhã pra 7 horas tá lá pra começar o serviço. Era bastante difícil. Depois... Nos primeiros tempos, eu ia a pé. Depois, comprei uma bicicleta. Daqui, dá quase 10 quilometro até lá. Também era puxado. Daí, depois consegui comprar uma moto, era um poquinho melhor [...]. (JEZABEL, 12 mar. 2015).

A jornada laboral era excessiva: começava antes das cinco horas, quando ela acordava para preparar o almoço do esposo e dos filhos. Até as cinco horas, ela deixava tudo pronto, arrumava pão para levar como refeição e saía de casa. Não podia levar marmita para a fábrica porque não tinha onde deixar e nem fogão para esquentar: "Arrumava o meu pão e levava, pra não levá comida, porque não tinha onde esquentá. Daí, eu levava o meu pão e comia. De noite, eu comia comida salgada com eles. O que sobrava do almoço nós jantava". Como se pode deduzir, o trabalho na indústria de confecção mexeu com os horários e com a forma de organização da vida familiar; sobretudo intensificou seu labor, pois, ao chegar em casa, por volta das dezenove horas, precisava ajudar seu esposo na lida com afazeres agrícolas e domésticos; de tal modo que fazia o trabalho da casa "[...] de noite, de manhã, de madrugada". 
Para dar conta de seus quefazeres, Jezabel mudou os hábitos alimentares da família. Adotou a prática de cozinhar os alimentos nos fins de semana: "No final de semana, eu fazia. Eu cozinhava o que podia cozinhá e deixá na geladeira pra durante a semana. Limpava a casa, fazia pão, lavava a roupa no final de semana." (JEZABEL, 12 mar. 2015).

Jezabel enfatizou que a necessidade de recursos financeiros a fez se submeter aos sacrifícios que o labor fabril lhe impunha. Seu esforço era impulsionado pelo desejo de garantir as necessidades básicas dos filhos, como roupas, calçados e materiais escolares. Ao frisar que, todos os dias, precisava andar - ou pedalar - dez quilômetros para trabalhar, apontava as mudanças no seu modo de viver e em suas condições de trabalho, ao mesmo tempo em que construía sua imagem de trabalhadora, pois estava dizendo que não eram todas as pessoas que fariam o que ela fez.

Em 1995, Jezabel entrou na indústria do vestuário. Saiu em 1999, porque a família decidiu se mudar para Foz do Iguaçu. Em 2000, voltaram para Santa Helena, e ela entrou em outra indústria, de onde saiu em 2006. Diferentemente de outros trabalhadores, Jezabel não se desvinculou de todo do trabalho rural, pois permaneceu morando no campo, de onde se deslocava para ir à sede municipal enquanto seu esposo se mantinha na lida agrária. A decisão de deixar o emprego na indústria se justificou por causa da saída dos filhos de casa, dos problemas de saúde de seu esposo e do aumento das tarefas domésticas.

[...] Tinha muito serviço e não vencia mais. Não dava mais pra ele ficar sozinho, não vencia aqui. E, pra mim trabalhar lá e vim fazê meu serviço em casa, não dava mais [...]. Daí, a idade começa pesar, a dificuldade começa chegar, a gente não vence mais tudo, a cabeça não ajuda mais como ajudava. Daí, tu não consegue associar [conciliar] uma coisa com outra, alguma coisa tem que ficar pra trás. (JEZABEL, 12 mar. 2015).

O esforço em se manter na indústria não suportou o excesso de trabalho. Foi um elemento central que a levou a se afastar do 
emprego de costureira. O labor industrial acelerou a vida dessa trabalhadora de modo que, depois de alguns anos de uma rotina estafante, se sentia esgotada. As limitações físicas e mentais decorriam desse processo exaustivo, embora as dinâmicas do trabalho industrial produzissem a sensação de que seria devido às mudanças do processo natural de envelhecimento que ela já não era capaz de se manter ali.

Após sair da empresa, ainda assim Jezabel ajudava uma filha que tinha uma confecção domiciliar. Somente depois de sofrer um acidente de moto parou de costurar, pois "[...] perdi o movimento de um pé, não podia mais costurar, ficou muito difícil, doía muito, não rendia mais. Daí, eu parei." (JEZABEL, 12 mar. 2015). Na ocasião da entrevista, disse que cuidava dos afazeres da casa e ajudava nas atividades da roça. Quanto à rotina laboral, frisou ter dias mais apurados, em que levantava às seis horas e ia até por volta das vinte e duas horas. Mas a diferença em relação ao emprego industrial era que fazia conforme conseguia: "Nós fizemos silagem em grão e aquele dia é apurado. $\mathrm{O}$ dia que faz silagem de milho verde também é um dia que não dá sossego, é apurado. Às vezes, vai até tarde da noite até que termina o serviço. Não é assim, um dia igual o outro." (JEZABEL, 12 mar. 2015). Ao dizer que a vida no campo e o trabalho rural não eram todos os dias iguais, ela estava dialogando com a realidade do labor industrial: este era monótono, intenso e repetitivo; no campo, havia dias com atividades mais intensas e outros mais tranquilos, quando podia cuidar das tarefas da casa e descansar. Como ela disse, "[...] Se tu quer levantar às nove horas, se tu quer levantar às cinco horas, tu vai a hora que tu quer. Se atrasou serviço, se ficou pra trás, o problema é o teu, né? E lá, não! Se atrasou o serviço, o problema não é de um só, [é] de muita gente." (JEZABEL, 12 mar. 2015).

Os trabalhadores que tinham experiência com a vida e o labor no campo, ao se iniciarem nessas indústrias, sentiam certo estranhamento, pois as dinâmicas e as exigências eram diferentes. Com efeito, Clara expôs as mudanças que o trabalho industrial ocasionou em sua vida: 
[...] Eu vou falar como foi o meu primeiro dia: apesar de eu já ter o curso de costura, eu não tinha assim, não tinha, vamos dizer assim, produção. Não tinha qualidade ainda na costura. Então, eu achei difícil, porque eles começaram a me cobrar. Então, por várias vezes, eu vinha pra casa chorando, por causa que, em casa, por mais que a gente trabalhava, a mãe não xingava. E daí, então, tinha uma estranha que vinha do meu lado e me xingava, que eu tava fazendo errado. (CLARA, 6 fev. 2012).

Desde adolescente, Clara trabalhava na agricultura com a família (seus pais tinham três alqueires e meio). Plantavam fumo, milho e mandioca, dentre outras culturas. Para ela, o trabalho rural tinha o sentido de algo familiar, fraternal; já as fábricas de costura eram algo que a assustava de início. Com a presença de pessoas "estranhas", pressionando e cobrando produção, ela demarcou aspectos que diferenciavam a relação com o trabalho, a começar pelo fato de que o labor na roça ela sabia fazer e, na fábrica, ela não dominava as operações a serem executadas. Além de não conhecer as etapas da produção, as pessoas "estranhas" não a ensinavam com a mesma paciência que tinham seus familiares. A "liberdade" e o prazer de um trabalho acolhedor eram substituídos pela agressividade do sistema da fábrica e por um ritmo acelerado.

Submeter-se e buscar se adaptar a essas condições era uma necessidade que expressava as dificuldades enfrentadas pelos agricultores. Também marcava mudanças na vida pessoal dos trabalhadores, sobretudo quando se viam em situações imprevistas, como separação ou gravidez. Clara acabara de ser mãe de sua primeira filha quando foi contratada para trabalhar na indústria de confecção. Ela argumentou que queria oferecer à filha mais do que o alimento necessário para viver; ou seja, "[...] roupas boas [...] coisas que ela vai gostar, né? Então, a necessidade de você querer dar uma coisa melhor do que eu tinha, dar uma coisa melhor pra ela. Então, acho que foi isso que me levou a querer ir trabalhar fora." (CLARA, 6 fev. 2012). A instabilidade do trabalho rural lançava a expectativa de conseguir emprego nas fábricas, pois os trabalhadores enxergavam a possibilidade de garantir um 
salário fixo no fim do mês. Isso os impulsionava a permanecer no labor fabril. Esse foi o processo vivido por Clara e seu esposo, funcionários da mesma indústria:

[...] Na fábrica, você tem o salário todo mês garantido e na agricultura, não. Que nem ele [o esposo], trabalhava no plantio quatro, cinco meses [...]. Ganha bem na agricultura, mais vamos dizer assim: só são quatro, cinco meses por ano, os outros meses - vamos dizer -, você tem que economizar aqueles quatro, cinco meses pra se manter por [pelo] resto do ano, né? $\mathrm{E}$ na fábrica não, se chove, se tem sol, você tá lá, mais você vai recebe, né? (CLARA, 6 fev. 2012).

Com efeito, de famílias ligadas ao meio rural, um número significativo dos trabalhadores, sobretudo aqueles com idade entre 35 e 50 anos, referia-se ao trabalho rural com positividade, como algo prazeroso; mas, ante a falta de terra e de condições de permanecer nela, precisaram rumar para a cidade, a fim de garantir a sobrevivência com trabalho na indústria.

Quanto às mudanças que o labor industrial ocasionou na vida dos trabalhadores da cidade, Ana destacou aspectos referentes às mudanças no conjunto familiar - seus costumes e valores.

[...] Muitas vezes, a gente não tem esse tempo de [ficar com a família], no final da tarde ou na hora do meio-dia [...]. Quase a gente não se vê mais, né? É muito difícil. É só à noite. Então, a gente senta, toma chimarrão, conversa aquele pouco e, logo, tem que cuidar dos afazer, que logo tá na hora de dormir de novo. Então, [...] hoje, as famílias perderam muito esse jeito de viver como família, né? Porque, quando eu era jovem, que a gente tinha... que eu estava com o pai e a mãe em casa, que a gente trabalhava na roça, a gente tinha mais aquele tempo de sentar na mesa na hora do meio-dia, todos junto embaixo de um pé de árvore, contar causo, dar risada, viver aquele momento, né? À noite, também, mesmo com tudo o trabalho que tem na lavoura... Só que aqui na [cidade]... Nós, que vivemos na cidade, né?,... Esse tempo vai, parece que ele vai se esgotando, que é minuto a minuto. Parece 
que o dia deveria de ter mais 12 , mais, mais 24 horas a mais pra fazer o que você tem que fazer. $E$ muitas vezes a gente deixa a desejar, né? (ANA, 10 jan. 2012).

Ana salientou as mudanças na organização de tempo, traçando um paralelo entre a experiência da agricultura e a vida na cidade. No meio rural, ainda existia certo respeito aos ritmos biológicos e sociais; na cidade, as pessoas viviam "num correcorre", não conseguiam se reunir, tampouco conversar sem estar preocupadas com os afazeres. Na cidade, a casa passou a ficar vazia, pois as pessoas se encontram à noite a fim de se prepararem para os compromissos da jornada de um novo dia.

Há quem veja o trabalho industrial com positividade ao ser comparado com o labor campesino porque vê as atividades na facção como algo mais leve:

Na lavoura, é mais sofrido, né? E a gente não tinha terra nossa mesmo, né? Então, era bem sofrido. [...] Mudou bastante devido a ser um trabalho braçal da lavoura, pesado, né? E a costura, além dela ser assim, mesmo ela sendo assim, uma... muitas horas sentado, ou coisa assim, mais ela é bem mais tranquilo. Não sei se é porque eu gosto. (DULCE, 12 mar. 2015).

Quanto ao ritmo de trabalho e ao cotidiano da vida urbana, Dulce frisou que "A rotina mudou muito, porque, mesmo tendo hora marcada pra tudo, é um serviço mais leve, né?" (DULCE, 12 mar. 2015).

Ante a referência de Ana e Dulce às mudanças na relação com o tempo (THOMPSON, 1998), cabe reiterar o que diz Izabel Cristina Ferreira Borsoi: ${ }^{~ "[. . .] ~ o ~ r i t m o ~ e ~ o ~ t e m p o ~ d e n t r o ~}$ de uma dinâmica de vida rural seguem, de certa forma, a lógica da natureza, com lida do nascer ao pôr do sol; na indústria, o ritmo e o tempo seguem a máquina e o relógio e, às vezes, nem

9 O estudo de Borsoi analisou a industrialização que vinha ocorrendo, no Ceará, especificamente em Horizonte, a partir de 1990. 
sequer o sol é vislumbrado durante o dia" (BORSOI, 2005, p. 79). $\mathrm{O}$ ponteiro do relógio controla cada minuto da vida, construindo uma racionalidade temporal diferente daquela do campo. Como destacou Eva, qualquer coisa que não seja produção é "matar tempo." (EVA, 4 nov. 2011). Na avaliação de Jezabel, o trabalho na agricultura era

[...] pesado. Só que tu trabalha a hora que tu pode, a hora que tu quer; o dia que tu não quer tu não precisa ir. Numa fábrica, tu tem um compromisso sério. Se tu tem alguém doente, tu tem que deixar, porque a fábrica não pode perder se você tem um doente, né? Se você não tá bem, não pode ir, a fábrica tá perdendo, né? Ao invés, aqui, não: se tu pode fazer hoje, tu faz; se tu não faz hoje, você faz amanhã. A diferença da fábrica da agricultura: aqui é serviço próprio, né? E lá, não! É um serviço que um depende do outro. No meu serviço, se eu faltasse - eu cortava a roupa pras outras costurar -, se eu faltasse, meu serviço ficava parado, tinha que ir a outra que não tinha muita experiência no meu lugar [...]. (JEZABEL, 12 mar. 2015).

Ao contratarem pessoal, as empresas passam a controlar o tempo e a interferir na vida dos funcionários. Diferentemente do que ocorre no labor no meio rural, o relógio determina a hora de entrar e sair das empresas. ${ }^{10}$ Esse processo de se deslocar da área campesina para o perímetro urbano - na avaliação de Ana - levava as pessoas a perder o controle do tempo e de suas vidas. Por vezes, sentem uma desorganização interna. Não se satisfazem consigo mesmas, pois percebem que o dia é curto para cumprir as obrigações diárias.

Sobre isso, eis o que disse Fátima:

Eu acho que todo trabalho tira tempo da gente, num importa que trabalho que seja. Tipo, os horários, né? [...] Mais, na medida do

\footnotetext{
10 Além da carga horária laboral diária, em alguns casos a hora extra é utilizada para completar a cena.
} 
possível, a gente tenta é intercalar as coisa, tenta dar atenção pros filho, pro marido, pra casa. Geralmente, a casa é quem fica bagunçada, os filhos sofrem um pouquinho a falta de atenção, né? Então, férias. A gente adora férias porque as férias são um momento assim pra gente ficar com os filhos, ficar com a família. Tem gente que tira férias e viaja; só que, daí, no meu caso, eu tiro férias pra ficar com os filhos, pra dar uma geral na casa, né? Então, [o trabalho fabril] interfere [na relação com o tempo]; mais não é, tipo assim, ruim também, né? Pelo fato de ser uma forma da gente ganhar a vida, né? (FÁTIMA, 20 dez. 2011).

$\mathrm{Na}$ avaliação dessa trabalhadora, a perda de controle sobre o tempo é algo inevitável ante as dinâmicas de sobrevivência a que precisavam se submeter. Como seres humanos, parece impossível cuidar de todos os aspectos da vida da forma que gostariam, por isso algo sempre era colocado em segundo plano. Nesse caso, Fátima destacou que a organização da casa perdeu a prioridade e que os filhos não recebiam a atenção devida. Isso porque os pais precisavam ganhar a vida com o trabalho, daí ser justificável a ausência de casa e do cuidado com a prole: "[...] eu acho ainda que justifica, justifica o fato de eu não ter muito tempo". Deixar o trabalho na agricultura, assim como deixar atividades de diarista ou empregada doméstica, implicava projetar a vida noutro sentido: o de um modo de viver e trabalhar que impunha valores trabalhistas alheios às suas experiências de classe.

Ao se referir às mudanças do trabalho na agricultura em relação ao trabalho nas facções de costura, Isabel foi enfática:

Olha! Pra mim, foi uma mudança bem radical, porque mudou como se fosse da noite pro dia. Cê vinha [em] uma coisa que era... Tua vida era uma coisa só, né? Aquela rotina: levantar, tirar o leite e ir pra roça. Depois, muda tudo. Tu tem que mudar, cuidar da casa, sair, ver as coisa na cidade. É completamente tudo diferente, demora pra conciliar tudo (ISABEL, 10 dez. 2011).

Essa dinâmica provoca uma autocobrança: os trabalhadores 
pensam que não fazem o suficiente, alimentando a sensação de que poderiam fazer sempre mais, pois "deixam a desejar" (ANA, 10 jan. 2012). Ana acreditava que a rotina da vida na cidade, o cumprir horário, além de ser fisicamente cansativo, com o passar do tempo "mata os valores, né? A família se acaba, e você não encontra um rumo pra seguir". Em sua avaliação, para manter os laços familiares, era necessária a prática religiosa: "[...] a religião faz parte da família. Eu acho que a família que não tem religião não segue. Eu acho que não tem como viver". Pude perceber que, para Ana, os valores familiares e religiosos articulavam um sentido e definiam o lugar do trabalho em sua vida. Entendia que a família era "um laço sagrado" e acreditava na necessidade de se reunir para conversar, sair juntos e ir à Igreja. Porém, a correria do cotidiano impedia que isso acontecesse: "[...] a gente não tá encontrando esse tempo quase, né?". Essa realidade despertava nela o desejo de voltar a viver no meio rural, onde havia passado a infância.

Segundo o ponto de vista dessas pessoas, o trabalho na indústria até melhorava suas condições econômicas; por outro lado, implicava mudanças que se expressavam em perdas. Ana manifestou isso com profundidade, uma vez que apontou a perda de controle sobre o tempo e sobre sua vida social, familiar e emocional. Ante tais perdas, pareciam lutar para estabelecer seus vínculos, buscando elementos e relações fora do ambiente laboral que pudessem dar sentido à vida e ao próprio trabalho. Exemplo disso está na conexão entre trabalho, família e prática religiosa: aspectos que tentavam preservar.

Esse processo tem dificultado cada vez mais a vida e a sobrevivências da classe trabalhadora e pobre. Visto sob a avaliação feita pelos que o viveram e vivem, percebe-se um deslocamento da valorização do trabalho para a produção. Esta desvalorização dos trabalhadores é narrada por eles a partir das perdas em relação a seus saberes e às formas de se relacionarem na produção, perdendo as relações que os identificavam com o trabalho (VARUSSA, 2012).

Entre os 36 entrevistados, 17 eram casados. Havia 10 
solteiros, 4 vivendo em união estável, 3 separados e 2 divorciados. Da mesma forma que o fator idade, o estado civil e a presença dos filhos pareceram ser uma variável importante na vida e no relacionamento que os trabalhadores estabeleciam com o serviço, pois a dependência do grupo familiar em relação à garantia da subsistência se constituía como um impulso à permanência no emprego. O maior número de casados estava entre o grupo da faixa etária com mais concentração nas empresas: entre 36 e 45 anos de idade; estes eram também os que tinham o maior número de filhos. As categorias ocupacionais dos cônjuges das casadas eram variadas: abrangiam atividades na agricultura - tratorista, hortigranjeiro, prestador de serviços para proprietários de terras e de aviários -; assalariados da indústria; auxiliares de produção da cooperativa Lar; costureiro; assalariados do comércio e do setor de serviços; técnico de informática; mecânico; operário de construção civil; vigilante de banco; instrutor de autoescola; jardineiro; motorista. Havia diversidade, também, no nível de renda das famílias, ainda que as informações obtidas nesse tópico tenham sido imprecisas. A renda mensal podia variar de um salário mínimo - quando um cônjuge estava desempregado - a três mil reais.

Foi entre as trabalhadoras de 36 a 55 anos de idade que encontrei índicos de que sonhavam em ser costureiras. Relataram dificuldades de conseguir emprego por causa da idade mais avançada e pela pouca escolaridade.

Dentre aquelas com idade entre 41 e 60 anos, a escolaridade variava de analfabeta ao ensino médio completo. Uma delas tinha cursado até a antiga segunda série; uma até a terceira série do primeiro grau; quatro tinham cursado até a quarta série; e duas, até a oitava série. Entre as quatro com ensino médio completo, duas haviam se formado depois de adultas, através do supletivo; uma com ensino médio incompleto havia estudado nesse sistema. Esses dados confirmam o que as entrevistadas disseram sobre dificuldades para estudar.

Para alguns trabalhadores da faixa etária entre 16 e 20 anos, o labor nas facções industriais constitui a primeira experiência 
trabalhista formal. Para outros, com idade entre 21 e 60 anos, o emprego nas facções de costura, em grande parte, era o primeiro com registro na carteira profissional. Oriundos de famílias ligadas à agricultura e pecuária, trabalhavam sem registro formal ou prestavam serviço como diaristas e domésticas. Os internos às empresas tinham faixa etária de 16 a 49 anos. Dentre os externos e as costureiras domiciliares, percebi a presença de pessoas com idade entre 40 e 60 anos. Em meio a estas, a idade mais avançada, algumas vezes, era argumento para expressar a experiência no ramo de confecções do vestuário.

Priscila concluiu o ensino fundamental aos 44 anos de idade; o que, para ela, representava uma de suas limitações para ter perspectivas de mudança profissional. Em outubro de 2011, fazia cinco meses que trabalhava numa confecção do vestuário, emprego que representava a realização do sonho de ter registro em carteira - "E outro sonho era trabaiar de carteira assinada, porque aquela que eu trabaiei na agricultura eu nunca tive carteira assinada. Primeira vez, com 44 ano - vou fazer 45 -, primeira vez a minha carteira foi assinada." (PRISCILA, 17 out. 2011). Antes de se empregar na fábrica, havia sido diarista por oito anos consecutivos; trabalhava uma vez por semana, em três casas. Somados os valores que recebia das três casas, disse que conseguia receber duzentos reais no mês.

Quanto às diferenças entre trabalhar de diarista e na indústria de confecção, Priscila frisou: "Passar bolso lá não é que nem passar roupa em casa". Ela fazia referência a mudanças quanto ao conhecimento do que fazia, pois, embora soubesse passar roupas e tenha feito isso por vários anos em sua residência e nos trabalhos que desenvolveu como diarista, sentia que não sabia fazer o que Ihe era cobrado na fábrica: "Ele [o gerente] te ajuda, ele pega o ferro, ele passa o primeiro pra tu entender. Pra mim, foi assim no começo, pra mim foi assim, porque tu ir passar bolso lá não é passar uma calça aqui, uma camisa aqui [...]." (PRISCILA, 17 out. 2011).

No caso de Priscila, a falta de estudos era vista como elemento que produzia nela a perspectiva de permanência naquele trabalho. 
Para os trabalhadores com idade entre 16 e 30 anos, estudar poderia ser o meio de conseguir sair das fábricas de confecções do vestuário. Em geral, estes não pretendiam permanecer por muito tempo em confecções de costura porque acreditavam que ainda conseguiriam algo, pelo menos, mais próximo do que projetavam para suas vidas. Os parâmetros para mudar de emprego eram definidos pelo descontentamento com as condições laborais, incluindo salário, que era considerado pouco ante o volume de serviço. Esses aspectos somavam-se a anseios pessoais como fazer uma graduação ou curso técnico em outro setor.

Nazaré terminou o ensino médio em 2011 e fez o vestibular para cursar Contabilidade na Universidade Estadual do Oeste do Paraná. Mas ficou "na lista de espera", o que ela viu como "grande avanço" porque era "muito difícil passar" sem fazer um curso preparatório. Por isso seguia com esperança: "Quem sabe ano que vem eu consiga?! Mais eu sonho muito com isso. É uma coisa que eu sou boa, que eu entendo e que eu me identifico, sabe?" (NAZARÉ, 24 jan. 2012). Ela via o emprego de costureira como algo que poderia lhe conceder as condições para se graduar em Contabilidade, pois isso era sua expectativa. Acreditava que poderia conciliar o serviço na facção de costura com os estudos.

Conforme disse essa entrevistada, o serviço de costureira era como outro qualquer que contribuía para suprir suas necessidades naquele momento. Mas definir a profissão que seguiria supunha ser algo para o resto da vida; para isso, seria preciso gostar do trabalho, porque, em sua concepção, uma pessoa que gosta de biologia e cursa uma graduação em letras "não vai se dar bem". Em sua perspectiva, o emprego na indústria de confecção era "uma saída" que havia encontrado para aquele momento presente:

Porque, no quê que eu ia trabalhar? Por exemplo, alguém que trabalha na prefeitura, o seu filho vai fazer o quê? Vai conseguir na área da prefeitura também, né? Não tem outra, muitas opções, porque em cidade pequena eles não aceitam pessoas sem experiência, né? Então, é aí que a gente consegue. (NAZARÉ, 24 jan. 2012). 
Na avaliação dessa entrevistada, a falta de opções na hora de procurar emprego era uma realidade que atingia toda a população do município, mas era pior para a classe trabalhadora e pobre. Ela estava enfatizando que, se tivesse oportunidade de emprego noutro setor, não estaria numa fábrica do vestuário. Mas, como filha de costureira, irmã de costureira e afilhada de costureira, tendia a fazer o mesmo. Nazaré enxergava sua trajetória em relação à de outras pessoas de sua idade cujos pais ocupavam cargos na prefeitura. Percebia que seu lugar social era diferente do lugar daqueles sujeitos. Ter um emprego público podia representar prestígio ante quem não tinha vínculo empregatício com os órgãos públicos (LANGARO, 2005).

Levando em consideração que a formação do setor de confecções do vestuário em Santa Helena deu-se entre os anos 1990 e 2000 e que o trabalho nessas confecções era a primeira experiência deles como trabalhadores da indústria, pode-se constatar que os sujeitos entrevistados para esta pesquisa já iniciaram suas trajetórias como trabalhadores de indústria convivendo com as mudanças caracterizadas pela historiografia como de "reestruturação produtiva". Eles tiveram suas trajetórias de trabalho construídas em um mercado caracterizado pelos processos de intensificação laboral, terceirização e informalidade (ANTUNES, 2006; GUIMARÃES, 2004).

Ressaltando as mudanças ocasionadas com o uso de máquinas eletrônicas, Diná elencou elementos das transformações produtivas vividas pela classe trabalhadora. Ela destacou as cobranças e as metas de produção:

[...] Antigamente, [as máquinas] era mais reta, manual, assim e tal. Hoje, já existe aquela eletrônica, né? Que tem uns detalhe a mais. Ela vai mais rápida, ela corta a linha, ela tem uns detalhe a mais, hoje. Até antigamente, num existia a pregadeira de bolso, hoje tem a pregadeira. Aqui não tem, mais em Missal, [onde] eu trabalhava, tinha pregadeira de bolso tipo eletrônica, ela prega bolso. Então, ela tirava o serviço de quatro costureiro, quatro costureiro produzia o que a máquina, em uma hora, produzia, entendeu? E a passadeira 
de bolso, que a própria máquina fazia, comprensava o bolso, tipo assim: imprensava e não precisava... Então, são claro, máquinas [...] mais rápidas. Tem a máquina de travete, principalmente. Você faz... Eu fazia um passante, você tinha que cortar o passante, o rapaz tinha que dobrar isso daqui. Hoje, não! Existe uma máquina que ela já pega, corta, já deixa dobradinho, a própria máquina costura, facilita muito, né? Então... Só que tem lugares... Como as máquinas são caras e... Essa, de pregar bolso, além dela ser cara, ela precisa de molde; todo molde, cada modelo de bolso é 500,600 reais, uma daquelas chapa, né? Então, o próprio patrão achava meio caro comprar toda vez. Então, o que eles podiam usar a máquina, eles usavam, a tradicional. (DINÁ, 30 jan. 2012).

$\mathrm{Na}$ conjuntura nacional, esse período é considerado como sendo de crise, marcado por políticas de abertura econômica, de desregulamentação financeira e de privatizações que repercutem na indústria nacional (JINKINGS; AMORIN, 2006, p. 339). De acordo com Jinkings e Amorin, desde 1990 as empresas têxteis com maior poderio econômico mantiveram-se no mercado à custa de intensa reestruturação produtiva. O setor de confecções do vestuário em Santa Helena se constitui dentro de uma conjuntura de transformações no mercado internacional e nacional.

O uso de tecnologia para aumentar a produtividade do trabalho, as novas formas de organização da produção e a introdução maciça da terceirização para reduzir os custos do trabalho resultaram em forte aumento dos níveis de desemprego e subemprego no setor têxtil. (JINKINGS; AMORIN, 2006, p. 339).

Em conformidade com esse processo, constatei que empresas de Santa Catarina contratavam os serviços de costureiras de Santa Helena, PR. Dulce, por exemplo, costurava na própria residência. Ela tinha sete funcionárias que produziam blusas, vestidos e saias. A empresa que contratava seus serviços era de Itajaí, SC; e as marcas das peças eram: Colcci, Coca Cola, Triton e Fórum. Disse-me que a produção ia para Itajaí e São Paulo; de lá, algumas peças eram exportadas. 
Os estudos sobre as indústrias de confecções têxteis e do vestuário têm demonstrado que recorrer à mão de obra domiciliar é uma dinâmica que tem se propagado Brasil afora. Conforme Abreu e Sorj, os empresários da indústria têxtil e do vestuário do Rio de Janeiro, em particular da zona norte, Baixada Fluminense e Niterói, adotavam essas práticas desde meados da década de 1970. Essas autoras constataram que o trabalho domiciliar no local de suas pesquisas estava caracterizado pelo isolamento das trabalhadoras, ignoradas pelos sindicatos e excluídas dos benefícios sociais atribuídos aos assalariados. ${ }^{11}$

Aqueles que se posicionam na defesa das mudanças recentes nas relações de produção argumentam que as mudanças organizacionais velozes acompanharam o desenvolvimento da inovação tecnológica e do mercado, acentuando a necessidade de aprendizagem e atualização continuas (PAULOS; MONIZ, 2013, p. 114).

Na perspectiva dos empresários de Santa Helena, atualizarse era algo necessário ao desenvolvimento das empresas e do município; tinham como prioridade a competição produtiva e costumavam lançá-la aos trabalhadores, o que, por vezes, tende a distanciar essas duas classes, ou seja, patrões e empregados. Podemos encontrar esse posicionamento em defesa das mudanças recentes nas relações de trabalho na fala do ex-prefeito municipal Silom Schimidt, que, em 1997, foi questionado pelo jornal Costa Oeste sobre as alternativas do governo municipal para o problema do desemprego. Eis sua resposta: "Estamos terceirizando os serviços públicos, que, aliás, é uma recomendação da nova política administrativa a terceirização. Terceirizando nós temos um resultado prático e rápido, com isso resolvemos o problema da geração de empregos" (COSTA OESTE, 1997, p. 9).

11 Abreu e Sorj destacam que esse tema pede uma análise que leve em conta fatores econômicos - por exemplo, redução de custos de produção, vistos através da transferência para os trabalhadores das despesas com energia, equipamentos e espaço - e que sejam percebidas e analisadas as relações de gênero e a divisão sexual do trabalho; isso porque o trabalho em domicílio contemporâneo seria realizado mais por mulheres. Cf.: ABREU; SORJ, 1993, p. 44. 
Para os trabalhadores, os resultados dessas mudanças só são rápidos porque, dentro de poucos anos, a saúde é consumida, e eles passam a sentir os efeitos através de doenças ocasionadas pelo trabalho. Com apenas três anos na linha de produção, Fátima sentiu os primeiros sinais de tendinite. Antes de se iniciarem nas fábricas, o organismo das trabalhadoras estava acostumado a um ritmo, e o trabalho fabril, acelerado, fez com que sentissem as alterações.

Além de elementos das possíveis melhorias que as máquinas eletrônicas podiam oferecer, facilitando o aumento da produção, Diná, citada anteriormente, pontuou que, em 2012, o número de empregados nessas indústrias de confecções do vestuário era reduzido ante o fim da década de 1990, quando ela se iniciou nesse setor, pois uma máquina eletrônica podia dispensar até três operários. Na concepção dos empresários, essas mudanças são vistas pelo viés da produtividade, uma vez que oferecem condições para aumentar a produção e obter mais lucros no final do mês. Contudo, essas chamadas inovações tecnológicas intensificam o trabalho e podem colocar os trabalhadores na condição de desempregados. De tal modo, passaram a viver com insegurança constante quanto a suas condições de sobrevivência.

Os trabalhadores foram atingidos pela instabilidade financeira, realidade que se torna mais penosa com as falências e o fechamento de empresas, que têm se tornado frequentes. Cabe dizer que quatro empresas de confecção de jeans que se instalaram no município entre os anos de 1998 e 2008 vieram a falir entre os anos 2003 e 2010.

Embora tenha diminuído o número de trabalhadores atuando diretamente no interior das fabricas, eles não foram eliminados. A intensificação do trabalho e a crescente instabilidade e precariedade do emprego são consequências dessas mudanças. Na lógica capitalista, parece que o processo de reestruturação seria algo inevitável e necessário para prosseguir o desenvolvimento e colocar as empresas nas relações de competitividade no mercado mundial (ALVES, 2007; ALVES, 2000).

Considerando as trajetórias dos trabalhadores das indústrias 
de confecções do vestuário em Santa Helena, é possível perceber que conviviam com a incerteza de emprego e de suas condições de vida, pois ora estavam empregadas, ora não. Às vezes, a vida de trabalho constituía vários tipos de ocupações, pois, para sobreviver, se submetiam a serviços temporários com o objetivo de conseguir renda mínima. Algumas vezes, a necessidade as levava a retomar os estudos. A discussão a respeito da escolaridade dos trabalhadores e as exigências de qualificação são questões que devem ser aprofundadas em outro momento.

Os relatos apontados pelos trabalhadores permitem questionar as produções acadêmicas que estabeleceram uma concepção de positividade no processo de mudanças que ocorre no mundo do trabalho e dos trabalhadores. Isso porque tais acontecimentos não apresentam um retorno produtivo para esses sujeitos; a eles coube um processo de perdas em relação ao prazer de trabalhar, do conhecimento e da saúde física e emocional. Na avaliação dos trabalhadores das confecções do vestuário de Santa Helena, as mudanças após a década de 1980 trouxeram a desvalorização de seus saberes e de seu modo de viver e de trabalhar, pois tiveram de deixar a vida e o trabalho agrícola para iniciar uma trajetória de vida como trabalhadores da indústria.

\section{Referências bibliográficas}

A ADMINISTRAÇÃO Silom e Mafini completa 150 dias: passaram-se quase 150 dias do governo Silom/Mafini. Costa Oeste, Santa Helena, PR, ano 2, p. 9, maio 1997.

ABREU, Alice Ranchel de Paiva. O avesso da moda. Trabalho a domicilio na indústria de confecção. São Paulo: Hucitec, 1986.

ABREU, Alice Rangel de Paiva; SORJ, Bila. Trabalho a domicílio nas sociedades contemporâneas: uma revisão da literatura recente. In: ABREU, Alice Rangel de Paiva; SORJ, Bila (Orgs.) O trabalho invisível: estudos sobre trabalhadores a domicílio no Brasil. Rio de Janeiro: Rio Fundo, 1993. 
AGÊNCIA NACIONAL DE ENERGIA ELÉTRICA/ANEEL. Royalties de municípios alagados pela formação do Lago de Itaipu. Disponível em: $<$ http://www.itaipu.gov.br/responsabilidade/royalties>. Acesso em $1^{\circ}$ fev. 2013.

ALVES, Giovanni. Dimensões da reestruturação produtiva: ensaios de sociologia do trabalho. 2. ed. Londrina: Praxis; Bauru: Canal 6, 2007.

ALVES, Giovanni. O novo (e precário) mundo do trabalho: Reestruturação produtiva e crise do sindicalismo. São Paulo: Boitempo, 2000.

ANTUNES, Ricardo (Org.). Riqueza e miséria do trabalho no Brasil. São Paulo: Boitempo, 2006.

BORSOI, Izabel Cristina Ferreira. O modo de vida dos novos operários: quando purgatório se torna paraíso. Fortaleza: Ed. UFC, 2005.

GEMELLI, Diane Daniela. Mobilidade territorial do trabalho como expressão da formação do trabalhador para o capital: Frigorífico de Aves da Copagril de Marechal Cândido Rondon/PR. 2011. Dissertação (Mestrado em Geografia) - Programa de Pós-Graduação em Geografia, Universidade Estadual do Oeste do Paraná, Campus de Francisco Beltrão, 2011.

GUIMARÃES, Nadya Araújo. Caminhos cruzados: estratégias de empresas e trajetórias de trabalhadores. São Paulo: USP; Curso de Pós-Graduação em Sociologia: Editora 34, 2004.

JINKINGS, Isabella; AMORIM, Elaine Regina Aguiar. Produção e desregulamentação na indústria têxtil e de confecção. In: ANTUNES, Ricardo (Org.). Riqueza e miséria do trabalho no Brasil. São Paulo: Boitempo, 2006.

KHOURY, Yara Aun. Muitas memórias, outras histórias: cultura e o sujeito na história. In: FENELON, Déa Ribeiro et al. (Orgs.). Muitas memórias, outras histórias. São Paulo: Olho D’Água, 2004.

LANGARO, Jiani Fernando. Para além de pioneiros e forasteiros: outras histórias do oeste do Paraná. 2005. Dissertação (Programa de PósGraduação em História) - Instituto de História, Universidade Federal de Uberlândia, 2005. 
LIMA, Angela Maria de Sousa. As faces da subcontratação do trabalho: um estudo com trabalhadoras e trabalhadores da confecção de roupas de Cianorte e Região. 2009. Tese (Doutorado em Ciências Sociais) Instituto de Filosofia e Ciências Humanas, Universidade Estadual de Campinas, 2009.

PAULOS, Margarida Ramires; MONIZ, António Brandão. Os trabalhadores do conhecimento num setor tradicional: o caso dos designers do vestuário. Sociologia, Problemas e Práticas, Lisboa, n. 72, p. 103-122, 2013.

PORTELLI, Alessandro. A filosofia e os fatos. Tempo, Niterói, n. 2, p. 59-72, 1996.

SILVA, Rosane Marçal. Trabalhadores e confecções em Santa Helena, PR (décadas de 1980-2000). 2015. 201 f. Tese (Programa de PósGraduação em História) - Instituto de História, Universidade Federal de Uberlândia, 2015.

THOMPSON, E. P. Costumes em Comum. São Paulo: Companhia das Letras, 1998.

VARUSSA, Rinaldo José. Metalúrgicos e as mudanças nas relações de trabalho: região de Jundiaí-SP, décadas de 1960 a 2000. História \& Perspectivas, Uberlândia, v. 25, n. 46, p. 85-10, jan./jun. 2012.

\section{Fontes orais}

ANA. Santa Helena, PR, 10 jan. 2012. Arquivo de MP3 (73 minutos). Entrevista concedida a Rosane Marçal da Silva na residência da entrevistada, então com 42 anos de idade.

CLARA. Santa Helena, PR, 6 fev. 2012. Arquivo de MP3 (63 minutos). Entrevista concedida a Rosane Marçal da Silva na residência da entrevistada, que tinha então a idade de 27 anos.

DINÁ. Santa Helena, PR, 30 jan. 2012. Arquivo de MP3 (46 minutos). Entrevista concedida a Rosane Marçal da Silva na empresa onde ela trabalhava. Ela estava com 38 anos de idade à época. 
DULCE. Santa Helena, PR, 12 mar. 2015. Arquivo de MP3 (45 minutos). Entrevista concedida a Rosane Marçal da Silva na residência da entrevistada, que tinha 49 anos de idade à época.

EVA. Santa Helena, PR, 4 nov. 2011. Arquivo de MP3 (64 minutos). Entrevista concedida a Rosane Marçal da Silva na residência da entrevistada. Ela estava com 49 anos de idade no momento da entrevista.

FÁTIMA. Santa Helena, PR, 20 dez. 2011. Arquivo de MP3 (89 minutos). Entrevista concedida a Rosane Marçal da Silva na residência da entrevistada, que tinha então 30 anos de idade.

ISABEL. Santa Helena, PR, 10 dez. 2011. Arquivo de MP3 (89 minutos). Entrevista concedida a Rosane Marçal da Silva na residência da entrevistada. Ela estava com 44 anos à época.

JEZABEL. Santa Helena, PR, 12 mar. 2015. Arquivo de MP3 (42 minutos). Entrevista concedida a Rosane Marçal da Silva na residência dela. A entrevistada tinha 57 anos à época.

NAZARÉ. Santa Helena, PR, 24 jan. 2012. Arquivo de MP3 (70 minutos). Entrevista concedida a Rosane Marçal da Silva na residência da entrevistada. Ela estava com 18 anos de idade à época.

PRISCILA. Santa Helena, PR, 17 out. 2011. Arquivo de MP3 (59 minutos). Entrevista concedida a Rosane Marçal da Silva na residência da entrevistada. Ela estava com 44 anos de idade à época.

SALOMÉ. Santa Helena, PR, 7 out. 2013. Arquivo de MP3 (40 minutos). Entrevista concedida a Rosane Marçal da Silva na empresa da entrevistada. Ela estava com 46 anos de idade à época da entrevista.

Recebido em abril de 2016.

Aprovado em julho de 2017. 